\title{
Derived Dental Pulp
}

National Cancer Institute

\section{Source}

National Cancer Institute. Derived Dental Pulp. NCI Thesaurus. Code C138973.

Dental pulp from a tooth. 